\title{
An automatic monitoring network installed in Tuscany (Italy) for studying possible geochemical precursory phenomena
}

\author{
R. Cioni, M. Guidi, L. Pierotti, and A. Scozzari \\ CNR Institute of Geoscience and Earth Resources, Pisa, Italy
}

Received: 18 July 2006 - Revised: 27 November 2006 - Accepted: 30 May 2007 - Published: 14 June 2007

\begin{abstract}
Since late 2002, a continuous automatic monitoring network (CAMN) was designed, built and installed in Tuscany (Italy), in order to investigate and define the geochemical response of the aquifers to the local seismic activity. The purpose of the investigation was to identify eventual earthquake precursors. The CAMN is constituted by two groups of five measurement stations each. A first group has been installed in the Serchio and Magra graben (Garfagnana and Lunigiana Valleys, Northern Tuscany), while the second one, in the area of Mt. Amiata (Southern Tuscany), an extinct volcano. The measured parameters are: $\mathrm{T}, \mathrm{pH}$, Eh, EC, dissolved $\mathrm{CO}_{2}$ and $\mathrm{CH}_{4}$. The results of three years of continuous monitoring can be summarised as follows: i) the monitoring stations made it possible to detect even small variations of the measured parameters, with respect to equivalent commercial devices; ii) acquired data made it possible to identify the groundwater circulation patterns; iii) in most locations, the observed trend of the acquired parameters is consistent with the periodic manual sampling results, and confirms the mixture of different water types that the hydrogeochemical model has determined.

The absence of seismic events with a sufficient energy precluded the possibility to locate anomalies, with the only exception of the Equi Terme site, where an increase in the dissolved $\mathrm{CO}_{2}$ content was observed twelve days before a $\mathrm{M}=3.7$ earthquake occurred at a distance of $3 \mathrm{~km}$ north of the monitoring station.

The CAMN resulted as being a suitable tool in order to investigate the anomalous variations of the physical, physicochemical and chemical parameters of aquifer systems as earthquake precursors.
\end{abstract}

\footnotetext{
Correspondence to: A. Scozzari

(a.scozzari@igg.cnr.it)
}

\section{Introduction}

The study of the earthquake precursory phenomena has attracted the interest of the scientific community for quite some time (Wakita et al., 1975; King, 1986, 1989; Thomas, 1988; Johansen et al., 1996; Wyss, 1997; Quattrocchi et al., 1999; Toutain and Baubron, 1999; Biagi et al., 2000; Johansen et al., 2000 Zanzari et al., 2001; Carapezza et al., 2005; Hartmann et al., 2006; Pulinets et al., 2007; Singh et al., 2007 and references therein); nevertheless, the problem of earthquake prediction has yet to be solved.

The consideration that stress field variation can determine permeability and porosity changes in the rocks and can modify the fluid flows from deep systems, has driven the choice of the more significant parameters to be examined by geochemical monitoring programs. Most of the literature data comes from the study of hydrothermal systems although cold and shallow aquifers have also been taken into consideration. Such studies have revealed significant modifications of physical and physico-chemical parameters (such as electrical conductivity, T, pH, Eh), and the concentration of dissolved ionic species and gases $\left(\mathrm{CO}_{2}, \mathrm{H}_{2}, \mathrm{Rn}, \mathrm{He}, \mathrm{CH}_{4}\right)$ in the waters in connection with strong earthquakes.

The development of geochemical monitoring methods and devices increased after the Tashkent (Uzbekistan) earthquake of 1966, that produced the first well documented Radon anomaly (Ulomov and Mavashev, 1967).

During the last two decades, an increasing interest in searching the geochemical precursors of earthquakes has also been observed in Italy (Bencini et al., 1990; Quattrocchi and Calcara, 1998; Garavaglia et al., 1999; Nucci et al., 2005; Quattrocchi et al., 1999; Cioni and Guidi, 2001; Zanzari et al., 2001 and references therein). In particular, IGG-CNR, PI has been involved in the development of various instrumental prototypes for the automatic measurement, of various parameters such as: i) the gas/vapour ratio and the concentrations of $\mathrm{H}_{2}, \mathrm{CH}_{4}$ and $\mathrm{CO}$ in the fumarolic fluids (magmatic

Published by Copernicus Publications on behalf of the European Geosciences Union. 


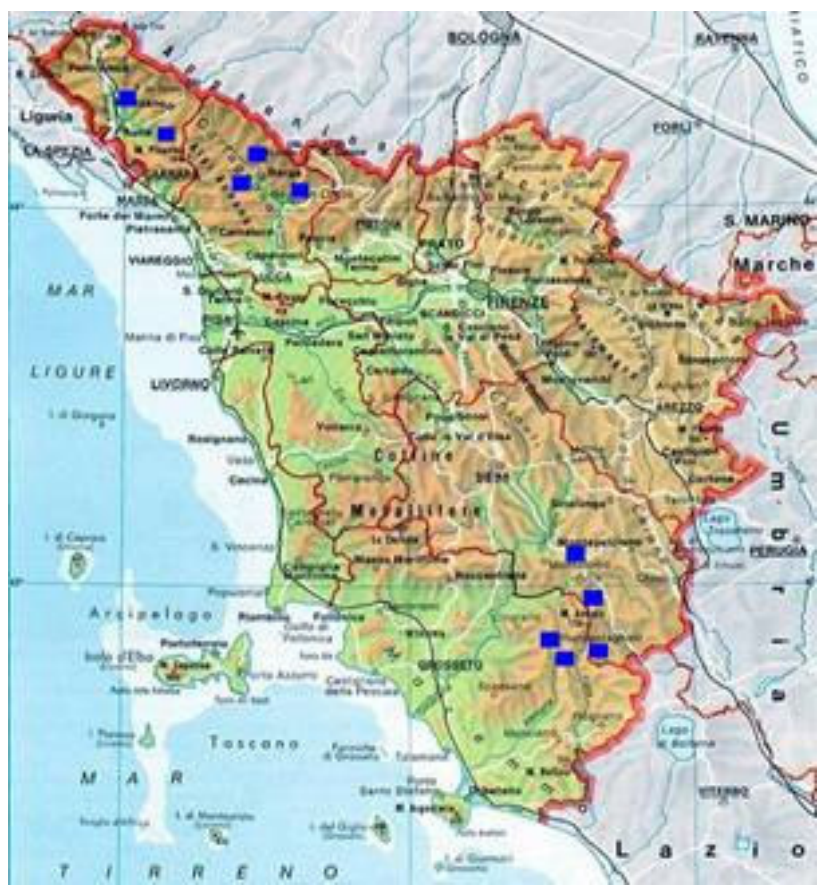

Fig. 1. The monitoring network.

and geothermal) and soil gases (Cioni et al., 1999; Cioni and Guidi, 2001); ii) the soil $\mathrm{CO}_{2}$ flux (Chiodini et al., 1996) and iii) $\mathrm{T}, \mathrm{pH}, \mathrm{Eh}, \mathrm{CE}, \mathrm{CO}_{2}, \mathrm{CH}_{4}$ in thermal water (Zanzari et al., 2001). The individuation of such precursors is the main objective of initiatives like the MICRAT project (Zanzari et al., 2001) that has been programmed after the violent 1997 Colfiorito earthquakes (M=5.8), Umbria, Italy. In that project, the automatic stations for the continuous monitoring of physical, physico-chemical and chemical parameters in waters of selected springs and wells are the same as those (with minimal changes) used in the work reported here.

The collection of good quality data series, with meaningful time coverage, is an essential step to drive the research regarding precursors to tangible results for the earthquake prediction. The precursory information can be derived from the identification of pre-seismic alterations and their subsequent validation through suitable data processing. A highresolution assessment strategy (both in time and in space), which could improve the existing methods of earthquake hazard assessment, may come from merging the experiences relating to the many aspects of the assessment process, such as modelling and individuation of relevant parameters, design and management of the monitoring networks (both manned and automatic), data processing and interpretation steps.

This paper describes the continuous automatic monitoring network (CAMN) designed, built and installed in Tuscany (Italy), for measuring physical, physico-chemical and chemical parameters in natural water. The network is constituted by two groups of five measurement stations each. They were installed in late 2002 in Garfagnana/Lunigiana area (N-W Tuscany) and in the area of Mt. Amiata, Southern Tuscany (Fig. 1).

\section{Seismotectonic framework}

Garfagnana, Lunigiana and Mt. Amiata regions belong to the inner zone of the Northern Apennine fold-and-thrust belt. This zone has been involved in the post-collision extensional tectonics since the Upper Miocene-Pliocene.

Such tectonic activity has produced horst and graben structures oriented from N-S to NW-SE that are transferred by NE-SW system (Carmignani et al., 1994; Jolivet et al., 1998).

Both Garfagnana (Serchio graben) and Lunigiana (Magra graben) belong to the most inner sector of the belt where the seismic sources, responsible for the strongest earthquakes of the northern Apennine, are located (e.g. the $M=6.5$ earthquake of September 1920).

The extensional processes in southern Tuscany have been accompanied by magmatic activity since the Upper Miocene, developing effusive and intrusive products traditionally attributed to the so-called Tuscan Magmatic Province (Marinelli, 1967; Serri et al., 1993; Peccerillo, 1999). Mt. Amiata, whose magmatic activity ceased about 0.3 M.y. ago, belongs to the extensive Tyrrhenian sector (Meletti and Valensise, 2004) that is characterized by high heat flow and crustal thinning. The whole zone is characterized by wide-spread but moderate seismicity (the maximum recorded magnitude has been 5.1 with epicentre in Piancastagnaio, 1919).

The extensional regime in both the Garfagnana-Lunigiana and Mt. Amiata area is confirmed by the focal mechanisms of recent earthquakes (Frepoli-Amato, 1997; Rosini et al., 1997; Frepoli-Amato, 2000).

An essential phase of the monitoring activities has been the selection of suitable sites for the installation of monitoring stations. This has been carried out on the basis of: i) hydrogeologic and structural studies in order to assess the underground fluid circulation regime; ii) a detailed geochemical study of all the natural manifestations present in the selected territories, such as cold and hot springs and gas emission zones; iii) logistical aspects.

\section{Selection of the installation sites}

The Serchio Valley and the adjacent north-western sector of the Apuan have been well studied. Numerous thermal springs are present in these areas, most of which are emerging in correspondence to the main neotectonic structures of the region (De Stefani, 1904; Pieri and Burichetti, 1930; Masini, 1956; Francalanci, 1956; Masini, 1964; Trevisa et al., 1971; Bencini et al., 1977; Fancelli and Agostini, 1980; Baldacci and Raggi, 1982; Baldacci et al., 1993; Fanelli et al., 1982; Calvi et al., 1999; Boschetti et al., 2005). These 
springs are fed by a regional circulation developing in a Mesozoic evaporite carbonate reservoir. The base of this aquifer comprises quartzites, quartzitic-micaceous conglomerates and sandstones, and Palaeozoic phyllites, while, in the Apennine sector, the top comprises the Oligocene shale and sandstone.

The main feeding areas of the deep reservoir are located in the extended carbonate outcrops of the Apuan Alps and the limited carbonate outcrops (Lima valley, Corfino and Soraggio) in the Apennine sector of the Serchio Valley.

With regard to the Magra Valley, in spite of the structural analogies with the Serchio Valley (both are semi-graben structures, Eva et al., 1978), some important hydrogeological features are not present. For example, in this region no important hydrothermal manifestations are present, perhaps due to the absence of recharge areas (both as to extension and piezometric gradient) of a possible deep reservoir (Baldacci and Raggi, 1982). Therefore, a detailed hydrogeochemical study was performed in 2002. A total of 150 water points were sampled and analysed. Moreover, more accurate hydrogeological and hydrogeochemical studies were performed in the Bagni di Lucca area in order to locate optimal sites for monitoring. This work has been necessary due to the high number of thermal springs present in the area. Based on the results of this multidisciplinary study, five water points suitable for the installation of the monitoring stations, were selected. They are: Bagni di Lucca (Bernabò spring), Gallicano (Capriz spring) and Pieve Fosciana (Prà di Lama spring) in Garfagnana, Equi Terme (main spring feeding the swimming pool of the thermal resort) and Villafranca in Lunigiana (well feeding the public swimming pool).

The Amiata area is characterized by two regional aquifers. The first is composed of volcanic rocks extending over an area of approximately $81 \mathrm{~km}^{2}$ while the second one is connected to the Mesozoic evaporite carbonate rocks and is fed by meteoric waters.

The latter is a confined aquifer, sandwiched between a Paleozoic basement (bottom) of low permeability, and the impermeable rock of Ligurian Units and neogene peliti (top) (Calamai et al., 1970; Duchi et al., 1992). The recharge area is composed of the carbonate rocks emerging in the highland east of Mt Amiata (Fancelli and Nuti, 1975; Celati et al., 1990).

In the preliminary campaign, 69 water points were sampled and analyzed and five sites were selected. They are: Piancastagnaio, Santa Fiora, Pian dei Renai and Bagnore, which are fed by the volcanic aquifer, and Bagno Vignoni borehole, which is fed by the evaporite carbonate aquifer.

The installation and start-up process of the monitoring systems in the Garfagnana-Lunigiana area begun in November 2002; in the Monte Amiata region it begun in June 2003.

From the day of installation, a periodic water sampling and manual measurement of the main physical and physicochemical parameters have been carried out on a monthly basis. Such activity has the double function of performing a

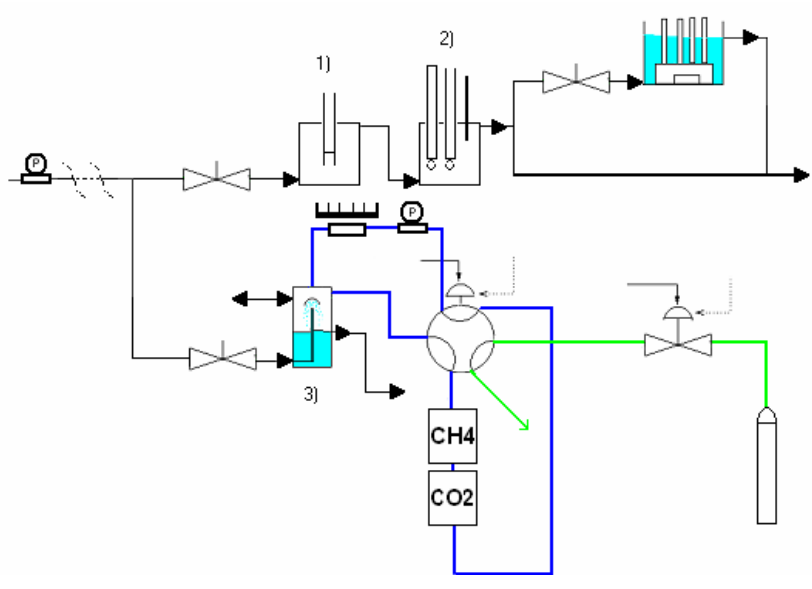

Fig. 2. Block diagram of the fluid measurement chain.

cross-check of the monitoring instrumentation, and carrying out additional chemical and isotopic analysis.

\section{The monitoring equipment installed in Tuscany}

All the stations of the monitoring network (Fig. 1) have a common architecture (Table 1) and record the following parameters: temperature $(\mathrm{T}), \mathrm{pH}$, electrical conductivity (EC), redox potential (ORP) and the content of $\mathrm{CO}_{2}$ and $\mathrm{CH}_{4}$ dissolved in water. Particular attention has been devoted to the determination of the dissolved $\mathrm{CO}_{2}$ content.

Each monitoring station can be divided into two sections (see Fig. 2), which are almost completely separated, even physically wise: one dedicated to the traditional physicochemical water parameters, the other to the concentration of dissolved gases.

The station operates with flowing water (about 5 litres per minute). The sampled water, naturally flowing (spring) or drawn from a well by a submersible pump, is split into two separate paths for the two sections mentioned above. For the physico-chemical parameters, there are two consecutive cells where conductivity (first cell), T, pH and ORP (second cell) are respectively measured. Dissolved gases are measured with a third cell, which belongs to the separate path.

In cell 3 (see Figs. 3a and 3b), gas is equilibrated by flowing in the headspace above the water level inside the cell, in a closed loop which includes the I.R. spectrometers and a lowflow pump, which provides the necessary gas circulation in the loop. The system is calibrated using an external standard gas supply. A six-way valve is configured to ensure that the measurement loop is never broken, neither during the calibration procedure, nor during the regular measurement. A solenoid valve is added to cut off the standard gas while the system is in the measurement configuration.

The submersible pumps have been chosen to withstand the temperature and the chemical aggressiveness that the water 
Table 1. The monitoring network.

\begin{tabular}{lcllllllll}
\hline Site name & Station \# & Ch 1 & Ch 2 & Ch 3 & Ch 4 & Ch 5 & Ch 6 & Ch 7 & Ch 8 \\
\hline Bagni di Lucca & 1 & pH & Eh & T & & EC & & & spare \\
Gallicano & 2 & pH & Eh & T & & EC & $\mathrm{CO}_{2}$ & $\mathrm{CH}_{4}$ & spare \\
Pieve Fosciana & 3 & pH & & T & & & $\mathrm{CO}_{2}$ & $\mathrm{CH}_{4}$ & spare \\
Equi Terme & 4 & pH & Eh & T & & EC & $\mathrm{CO}_{2}$ & $\mathrm{CH}_{4}$ & spare \\
Villafranca & 5 & pH & Eh & T & T & EC & $\mathrm{CO}_{2}$ & $\mathrm{CH}_{4}$ & spare \\
Bagnore & 6 & pH & Eh & T & & EC & $\mathrm{CO}_{2}$ & $\mathrm{CH}_{4}$ & spare \\
Piancastagnaio & 7 & pH & Eh & T & & EC & $\mathrm{CO}_{2}$ & $\mathrm{CH}_{4}$ & spare \\
Santa Fiora & 8 & pH & Eh & T & EC & $\mathrm{CO}_{2}$ & $\mathrm{CH}_{4}$ & spare \\
Pian dei Renai & 9 & pH & Eh & T & EC & $\mathrm{CO}_{2}$ & $\mathrm{CH}_{4}$ & spare \\
Bagno Vignoni & 10 & pH & Eh & T & EC & $\mathrm{CO}_{2}$ & $\mathrm{CH}_{4}$ & spare \\
\hline
\end{tabular}
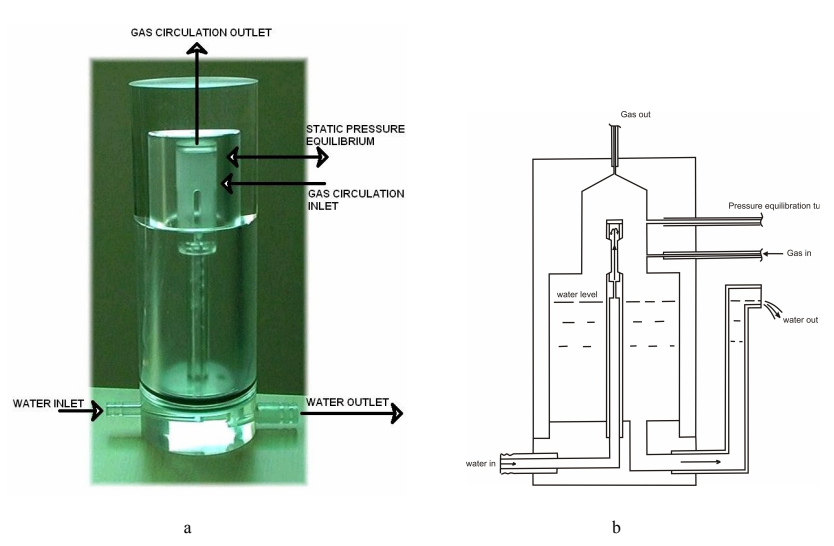

Fig. 3. The gas cell.

exhibits in some of the installation sites; wet parts of the pumps are made of a plastic self-lubricating material able to run at temperatures up to $90^{\circ} \mathrm{C}$. In addition a suitable delivery/head curve has been selected to obtain the required water flow without self-heating issues for both the motor and the pump, which would cause the transfer of heat to the water. Moreover, water adduction tubes and cells are thermally insulated to reduce the heat loss to the environment, which would lower the temperature of the sampled water.

As to the electronics, a simplified block diagram is reported in Fig. 4. All the signals are isolated (galvanic isolation via transformer) and conditioned with a fifth-order low-pass filter having a high DC accuracy, according to the slowness (speed) of the measurements acquired. Signals come from the sensors to the signal conditioning block either directly or via some analog front-end. As to the highimpedance electrodes ( $\mathrm{pH}$ and ORP measurement), a differential electrometer (an amplifier with a very low input current loss) has been custom designed to meet high specifications exceeding the usual market availability. The electrometer provides three-port isolation and operates over a wide temperature range; in particular, care has been taken to minimise the effect of ambient temperature drifts on the measurement of $\mathrm{pH}$.

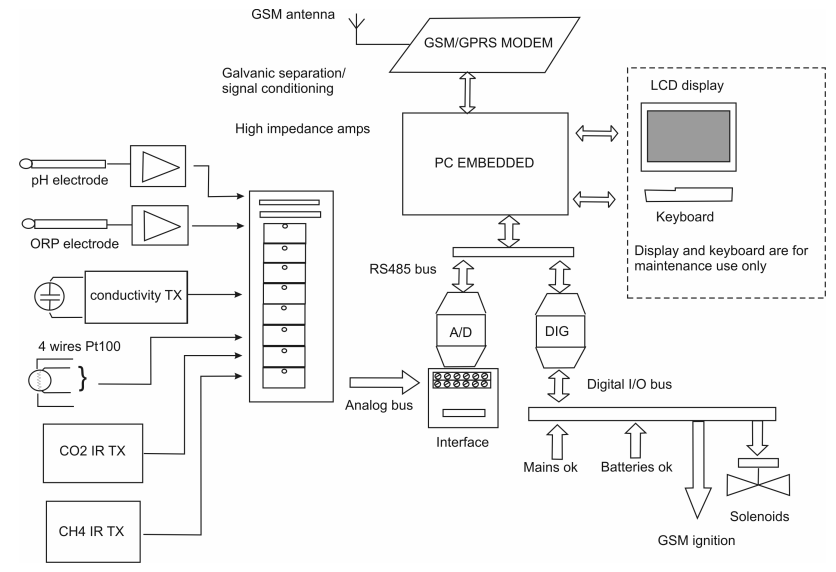

Fig. 4. Simplified block diagram of the apparatus.

Table 2 shows the essential specifications of the measurement chain for each channel; as for the $\mathrm{pH}$ and ORP measurements, accuracy is intended to be the maximum deviation from the room temperature calibration over the whole working temperature range $\left(-20^{\circ} \ldots+70^{\circ} \mathrm{C}\right)$.

The core of the data-logging system is a Personal Computer in PC/104 format, which runs a program that controls all the activities of the station via the onboard serial ports. An RS485 port is used to communicate with the data conversion devices, which perform all the input/output processes. One of the two devices (A/D) performs the multiplexing and the analog-to-digital conversion of the input channels; the other one (DIG) manages the digital input/output signals to control the solenoid valves, to switch on the modem, and to check the mains power line and the state of the batteries.

Data can be downloaded both onsite and in remote, via a GSM/GPRS modem connected to the embedded PC. The remote link also makes it possible to see real-time values for all the parameters and to interact with the machine in order to check and modify its internal parameters, in addition to the pure download feature. 
Table 2. Characteristics of the sensors.

\begin{tabular}{llll}
\hline Parameter & Sensor & Analytical range & Accuracy \\
\hline $\mathrm{pH}$ & HA405-DXK-S8/120 combination Xerolit glass elec- & $2 \div 14 \mathrm{pH}$ & $<0.03 \mathrm{pH}$ \\
& trode (Ag/AgCl reference) & & \\
Eh & Pt4805-DXK-S8/120 combination platinum electrode & $-1250 \div 1250 \mathrm{mV}$ & $<1.5 \mathrm{mV}$ \\
Conductivity & Hanna HT8936 four electrode configuration (platinum & $0 \div 19.99 \mathrm{mS} \cdot \mathrm{cm}^{-1}$ & $<2 \%$ of range \\
& rings) & $0 \div 100{ }^{\circ} \mathrm{C}$ & $<0.15^{\circ} \mathrm{C}$ at $0^{\circ} \mathrm{C}$ \\
Temperature & PT100 (class A according to BS1904 standard) & $0 \div 10 \% 0 \div 100 \%$ & $<2 \%$ of range \\
Carbon dioxide & IR cell & $0 \div 10 \%$ & $<2 \%$ of range \\
Methane & IR cell & & \\
\hline
\end{tabular}

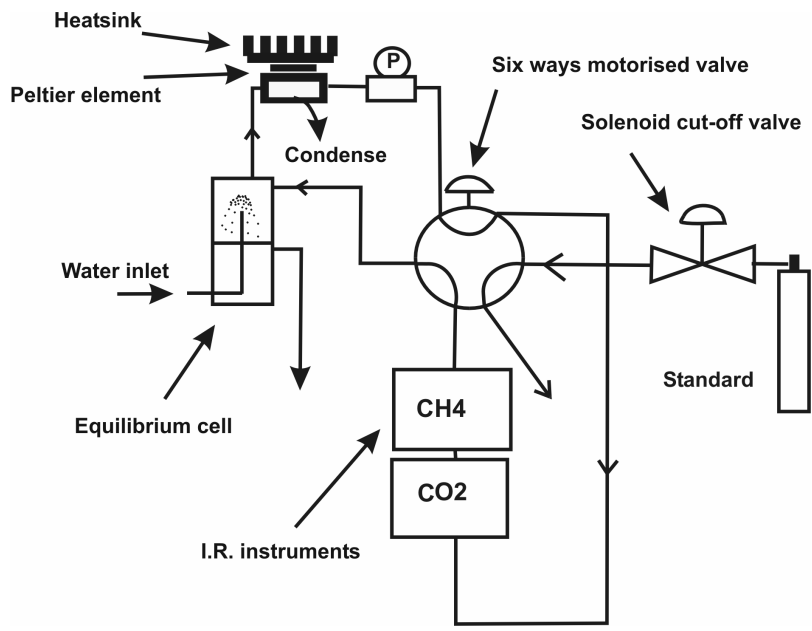

Fig. 5. Block diagram of the gas measurement section.

Data are acquired once per second; the average value, median value and variance of the samples collected over a period of $5 \mathrm{~min}$ are recorded in a local removable non-volatile memory (Compact Flash card).

Both the solenoid valve and the six-way valve reported in Fig. 5 (the latter of which is actually simulated by means of four three-way solenoid valves) are driven by the embedded PC to perform a daily calibration, during which time the cutoff valve is opened and the six way valve is switched, making the standard gas enter into the measurement loop.

It is imperative that liquid water from condensation does not reach the optical measurement cells, as this would induce major errors and eventually damage the optical cells. To address this issue, the gas temperature is lowered below the minimum expected temperature within the cells with a heat exchanger based on a Peltier element (solid state heat pump), and the condensate is separated. In this way, pre-conditioned dry gas is sent to the cells.

The software that runs on the embedded PC installed in each measurement station has been custom-designed for the specific application. It consists in a data logger application that manages all of the analog and digital signals which are
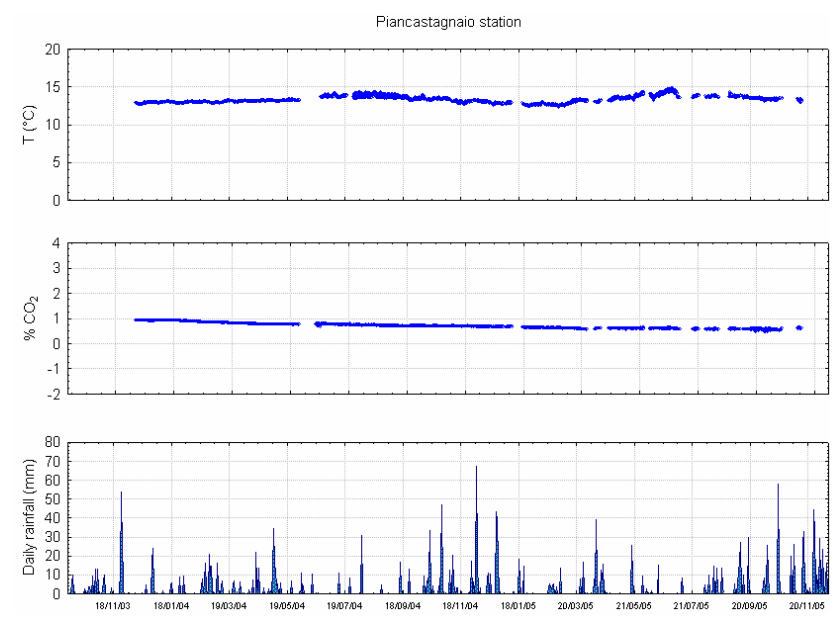

Fig. 6. Continuous monitoring at the Piancastagnaio station. The rainfall data have been recorded at the Castel del Piano station.

fed into the device, plus the communication protocol, the calibration process, the local database management and the calculation of the statistics about collected data. Data are transmitted in a packed binary compact form to allow for remote storage and post-processing at IGG headquarters in Pisa. Additional filtering, such as moving window or median filtering, as well as eventual subsampling, usually down to a rate of one sample/hour is carried out before any other processing.

Data series obtained by such signal conditioning processes are then studied with traditional multivariate analyses techniques.

\section{Results}

Some of the monitored locations show relatively large variations of the observed parameters that are generally explained by natural mixing processes between different water types. The different degree of mixing, due to several factors such as rainfall, can make the interpretation of data relating to the presence of eventual precursors generally difficult. Thus, in the case of signal processing, one of the most challenging 

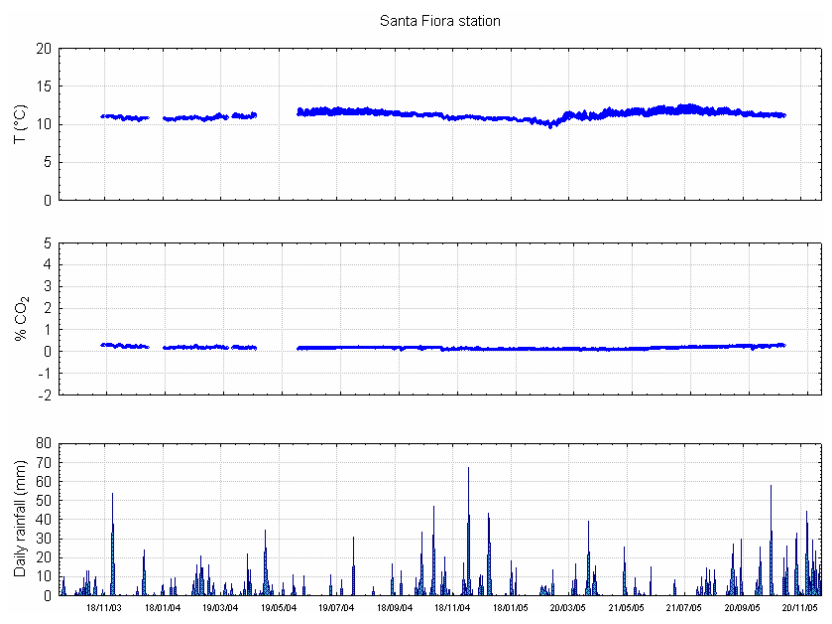

Fig. 7. Continuous monitoring at the Santa Fiora station. The rainfall data have been recorded at the Castel del Piano station.
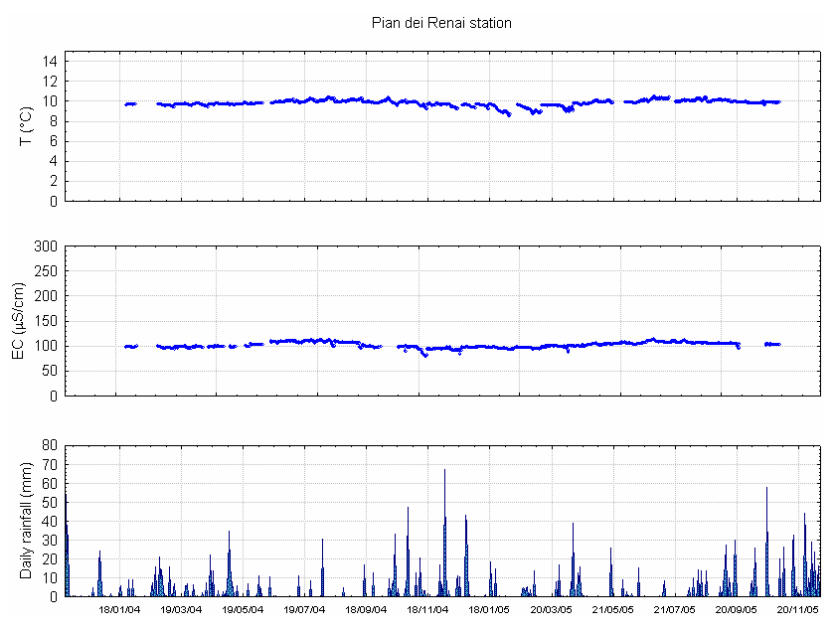

Fig. 8. Continuous monitoring at the Pian dei Renai station. The rainfall data have been recorded at the Castel del Piano station.

activities lies in the extraction of features from the collected data series, that are relevant to the detection of eventual precursors, selected to have the lowest possible sensitivity from unwanted contributions such as meteorological parameters, looking for the evidence of deep effects on the mixing processes.

In the large dataset collected (10 monitoring devices with 8 channels each, recording data every 5 min since year 2003) there are many situations in which the time series are clearly affected by the influence of unwanted factors, such as the abovementioned rainfall. On the other hand, the absence of seismic events with sufficient energy precluded the possibility of locating anomalies, with only one exception up to now.

In fact, only at the monitoring station located in Equi Terme was there an increase in the $\mathrm{CO}_{2}$ value, which was observed twelve days before a $\mathrm{M}=3.7$ earthquake that occurred
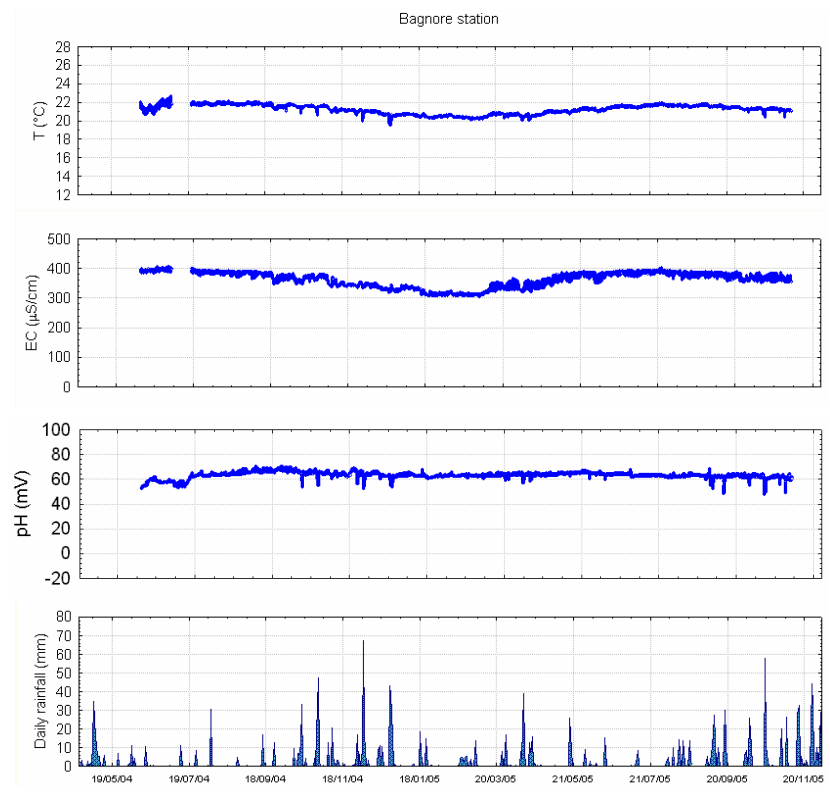

Fig. 9. Continuous monitoring at the Bagnore station. The rainfall data have been recorded at the Castel del Piano station.

at a distance of $3 \mathrm{~km}$ north of the installation site. The relationship between the dissolved $\mathrm{CO}_{2}$ concentration and the other water physical parameters collected under this circumstance, may be seen as a precursory signal as discussed further in this paper.

\subsection{An overview of the collected data}

The spring waters of Piancastagnaio, Santa Fiora and Pian dei Renai (Figs. 6, 7, 8), that are fed by the aquifer developed in volcanic rocks of Mt. Amiata, belong to the $\mathrm{Ca}-\mathrm{HCO}_{3}$ water type. They show temperatures ranging between $10^{\circ} \mathrm{C}$ and $13^{\circ} \mathrm{C}$, and a very low TDS content (from 70 to $75 \mathrm{mg} / \mathrm{l}$ ), with quite a low maturity degree.

The $\mathrm{Ca}-\mathrm{SO}_{4}$ spring water of Bagnore has a positive Eh value (average $+306 \mathrm{mV}$ ) with a temperature of $21.5^{\circ} \mathrm{C}$. Its salinity is low $(240 \mathrm{mg} / \mathrm{l})$, while the $\mathrm{CO}_{2}$ concentration in dissolved gases is about 3.6\%. For this spring, which is also fed by the volcanic rocks of Mt. Amiata, the analytical data indicate some contamination by geothermal fluids rich in $\mathrm{CO}_{2}, \mathrm{H}_{2} \mathrm{~S}$ and $\mathrm{H}_{3} \mathrm{BO}_{3}$. Although the time-series analysis (Fig. 9) indicates that the Bagnore spring water is clearly influenced by local rain, the evidence of contamination by geothermal fluids indicates the site as particularly suitable to detect those eventual deep variations of the physical, physico-chemical and chemical parameters that can precede an earthquake.

The water of the Bagno Vignoni shallow borehole belongs to the $\mathrm{Ca}-\mathrm{SO}_{4}$ type. It has a negative $\mathrm{Eh}$ value (average $-106 \mathrm{mV}$ ) and shows a mean temperature of $48.4^{\circ} \mathrm{C}$. The TDS is quite constant at around $3.9 \mathrm{~g} / \mathrm{l}$ while the $\mathrm{CO}_{2}$ partial 

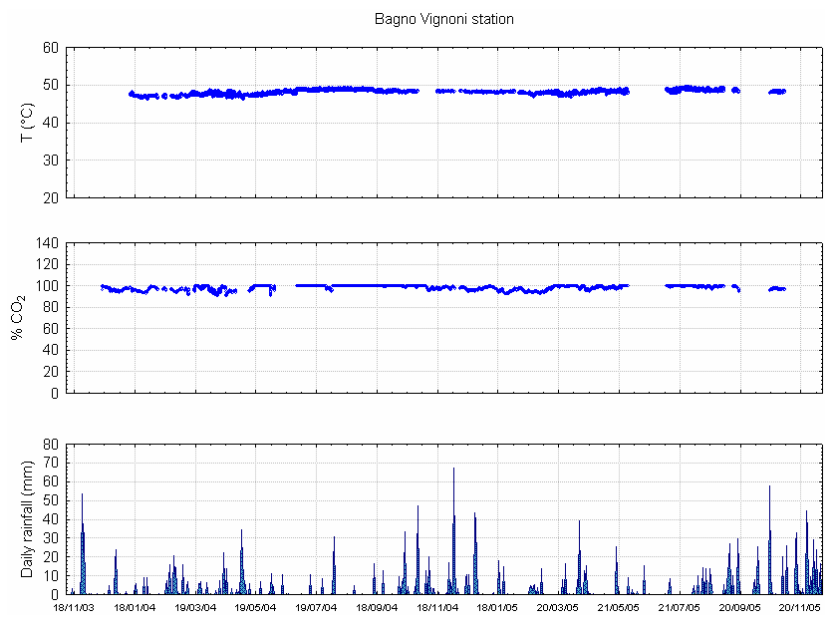

Fig. 10. Continuous monitoring at the Bagno Vignoni station. The rainfall data have been recorded at the Castel del Piano station.
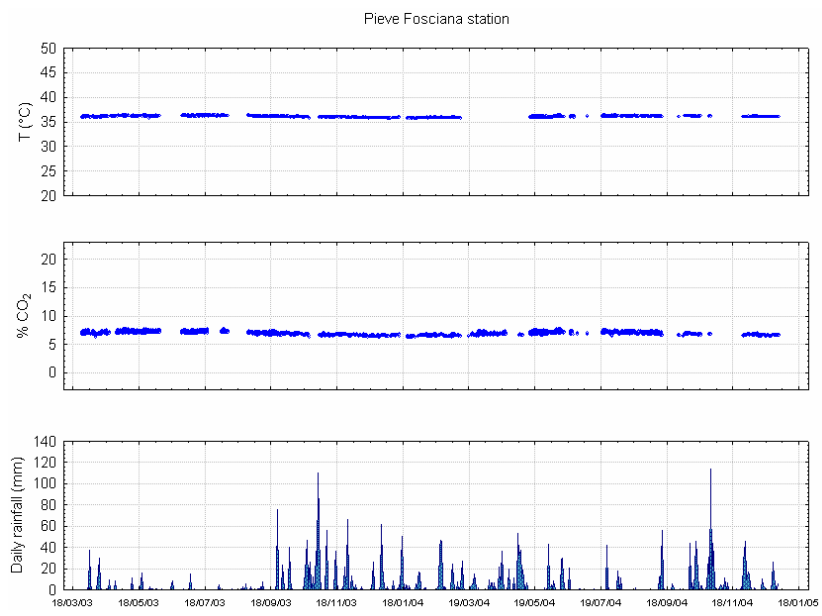

Fig. 11. Continuous monitoring at the Pieve Fosciana station. The rainfall data have been recorded at the Villa Collemandina station.

pressure approximates 1 bar. This water, that is representative of deep circulation in a Mesozoic evaporite carbonate reservoir, displays very constant physical and chemical characteristics over time (Fig. 10). No influence by local rain, or mixing processes with other deeper circulation water types has been observed. Therefore it appears to be very favourable for recognizing anomalous input of different fluids connected to the processes of seismic energy accumulation.

As far as the Garfagnana and Lunigiana areas are concerned, the Pieve Fosciana water belongs to the Na-Cl type, whit a a stable temperature of $36.5^{\circ} \mathrm{C}$ and a TDS of $5.9 \mathrm{~g} / \mathrm{l}$, while $\mathrm{CO}_{2}$ concentration in dissolved gases is $7.5 \%$.

Bernabò spring water (Bagni di Lucca) belongs to $\mathrm{Ca}-\mathrm{SO}_{4}$ type. It shows a temperature of $40.5^{\circ} \mathrm{C}$ and a salinity of about $2.5 \mathrm{~g} / \mathrm{l}$.
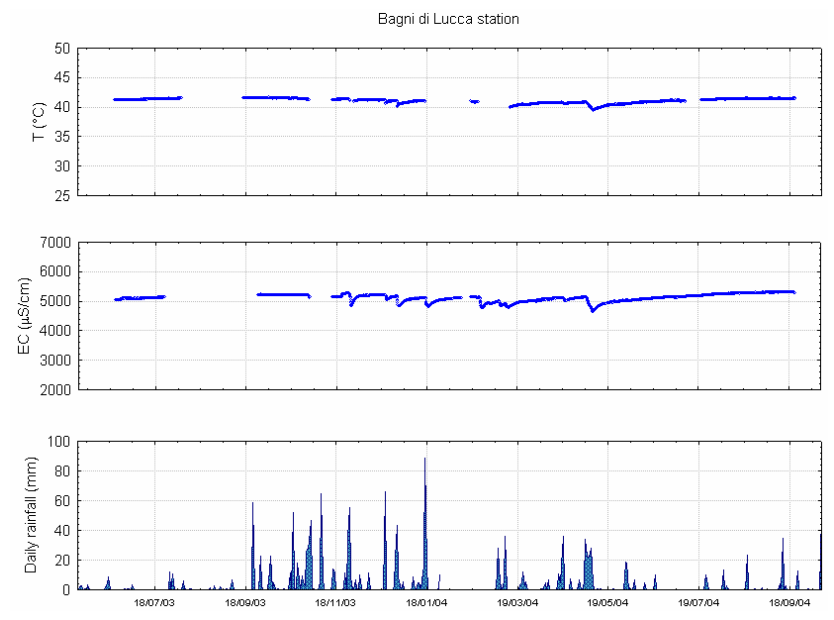

Fig. 12. Continuous monitoring at the Bagni di Lucca station. The rainfall data have been recorded at the Bagni di Lucca station.
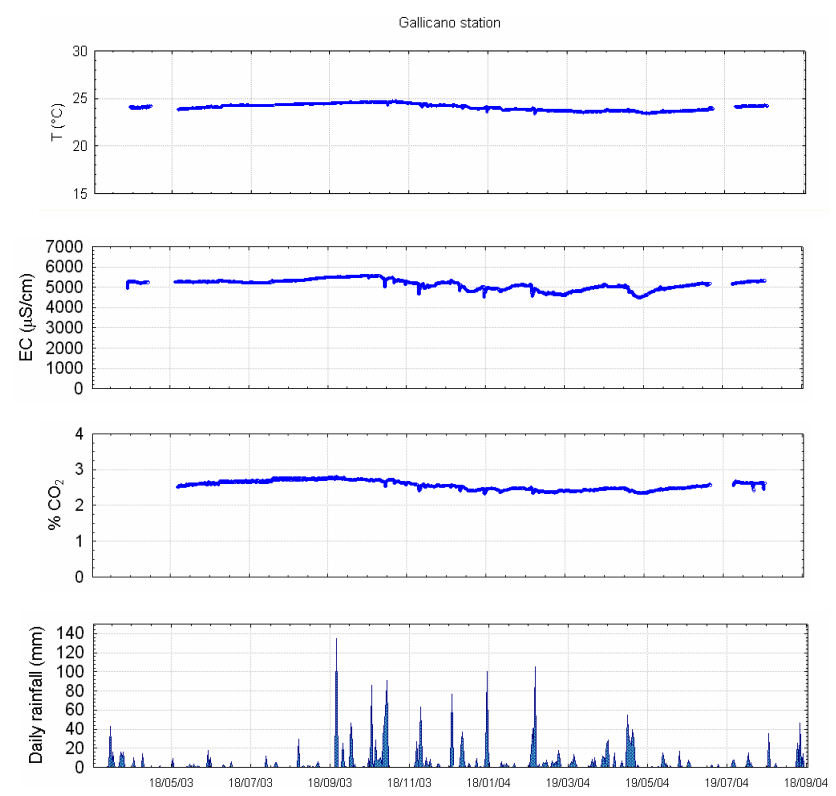

Fig. 13. Continuous monitoring at the Gallicano station. The rainfall data have been recorded at the Careggine station.

Both Pieve Fosciana and Bagni di Lucca emergences are artesian springs. They rise in the Apennine sector of the Serchio graben where the Oligocenic shales and sandstones, which represent quite an impermeable cover, outcrop abundantly. For this reason, the chemical and physico-chemical characteristics acquired by the water in the deep aquifer are maintained during their ascent to the surface (Figs. 11 and 12).

Gallicano spring water belongs to the $\mathrm{Na}-\mathrm{Ca}-\mathrm{Cl}$ water type. It has a positive Eh value (average $+365 \mathrm{mV}$ ) while the water temperature ranges from $23.7^{\circ} \mathrm{C}$ (June 2004) and $24.9^{\circ} \mathrm{C}$ (October 2003). Its TDS ranges from 3.1 to $3.9 \mathrm{~g} / \mathrm{l}$, 

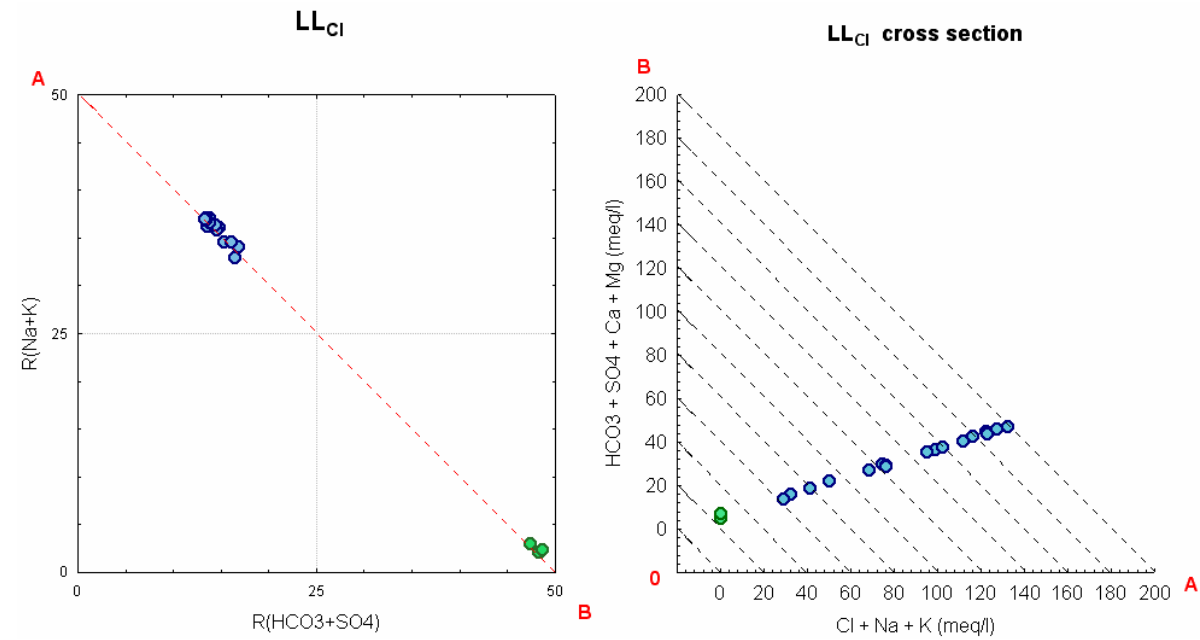

Fig. 14. $\mathrm{LL}_{C l}$ square diagram and $\mathrm{LL}_{C l}$ cross section (Langelier and Ludwig, 1942) for Equi spring waters (blue circles) and for karst shallow spring waters sampled in the Equi hydrogeologic basin (green circles).
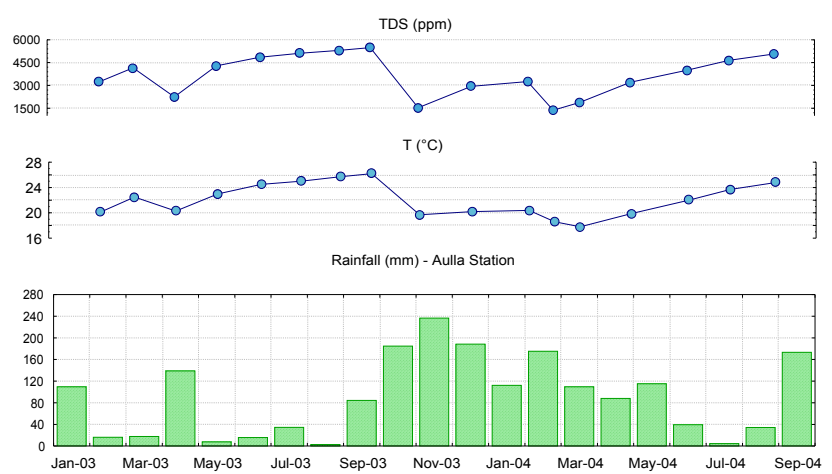

Fig. 15. Variation in time of $T$ and TDS compared with monthly rainfall.

while the $\mathrm{CO}_{2}$ concentration in dissolved gases is around $2.5 \%$ (Fig. 13). The Gallicano emergence is a contact spring that rises in the Apuan sector of the Serchio graben where the carbonate rocks outcrop abundantly. For this spring, mixing processes between a deep component (a mixture of two different deep-water-types) and a shallow groundwater, have been recognized. The deep component rises along the NWSE normal fault at the eastern edge of the Apuan Alps, while the shallow component is a diluted Ca-bicarbonate water.

The Villafranca well water belongs to the $\mathrm{Ca}-\mathrm{HCO}_{3}$ water type. It has a negative Eh value (average $-200 \mathrm{mV}$ ) and a temperature of $15.4^{\circ} \mathrm{C}$. Its salinity is low $(235 \mathrm{mg} / \mathrm{l})$, while the $\mathrm{CO}_{2}$ concentration in dissolved gases is about $0.15 \%$.

The Equi Terme spring emerges along the north-western edge of the carbonate outcrops of the Apuan Alps. Specifically, the spring is located along the NE-SW transfer system between the Magra graben and the Serchio graben. Here, rising thermal water mixes with superficial karst water; more details will be given in the next paragraph.

\subsection{A case study: the Equi Terme site}

The Equi Terme monitoring station was installed in 2003 (21 September) at the main spring $(Q=100=1 / \mathrm{s})$ that feeds the thermal resort and the thermal swimming-pool. Between February 2003 and August 2004, the Equi Terme spring was also sampled monthly for hydrogeochemical and isotopic analyses. All samples belong to the $\mathrm{Na}-\mathrm{Cl}$ water type (Fig. 14) and their TDS ranges from 1.2 to $5.5 \mathrm{~g} / \mathrm{l}$ (Fig. 15). The temperature values lie in the interval between $17.8^{\circ} \mathrm{C}$ (March 2003) and $26.2^{\circ} \mathrm{C}$ (September 2003).

Analysed samples have shown that the Equi Terme water originates from a mixing, at a different degrees, of karst shallow $\mathrm{Ca}-\mathrm{HCO}_{3}$ water and deep $\mathrm{Na}-\mathrm{Cl}$ water (Fig. 14). Their mixing ratio depends mainly on the effect of the rainwater that recharges the karst superficial circulation, as seen in Fig. 15.

Hydrogeochemical and isotopic data, associated with the time series of all the parameters acquired by the monitoring equipment, together with the structural and hydrogeological context, allow us to define a conceptual model of groundwater flow.

The recharge area of deep water circulation that feeds the Equi Terme spring is located in the carbonate rocks outcropping in the northern sector of Apuan Alps: the underground circulation, guided by metamorphic basement, follows a northerly direction. The rise of deep thermal water, after having deeply interacted with Triassic marine evaporites of the "Tuscan series", occurs along low and high-angle fault systems, located at the northern edge of Apuane Alps. Such rising water comes into contact with the cold iposaline water of the shallow circulation, recharged by the local rain water. Rainfall influences all the measured parameters, including the $\mathrm{CO}_{2}$ concentration (Fig. 16). 

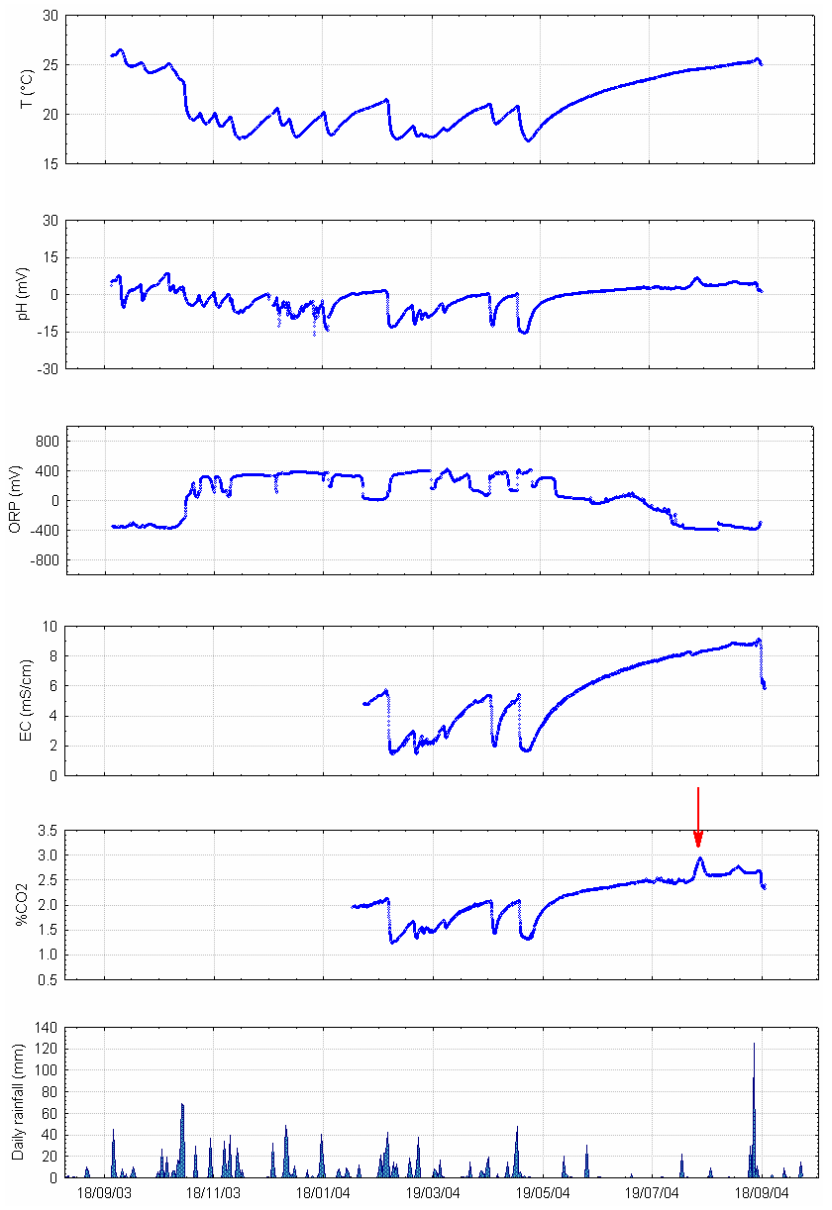

Fig. 16. Continuous monitoring at Equi station. The rainfall data have been recorded at the Aulla station.
$\mathrm{CO}_{2} \mathrm{vs} \mathrm{T}$

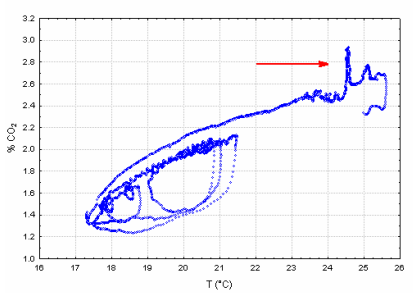

$\mathrm{CO}_{2}$ vs EC

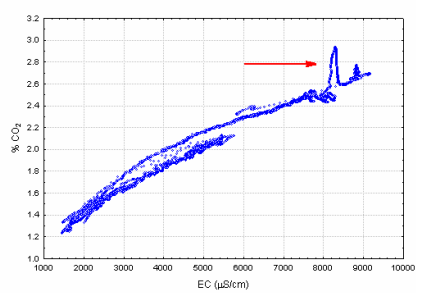

Fig. 17. $\mathrm{CO}_{2}$ vs. $\mathrm{T}$ and $\mathrm{CO}_{2}$ vs. EC scatterplot; time interval: 9 February 2004-20 September 2004.

In the middle of August 2004, a sharp increase in $\mathrm{CO}_{2}$ value in the dissolved gas, apparently uncorrelated with $\mathrm{T}$ and EC (Fig. 17) neither with the rainfall trend (Fig. 16), was detected.

This was the only exception in the monitoring period discussed here (between September 2003 and June 2005), since the acquired signals were always distinguished by a high degree of correlation between T, EC and $\mathrm{CO}_{2}$ values.
EC vs T

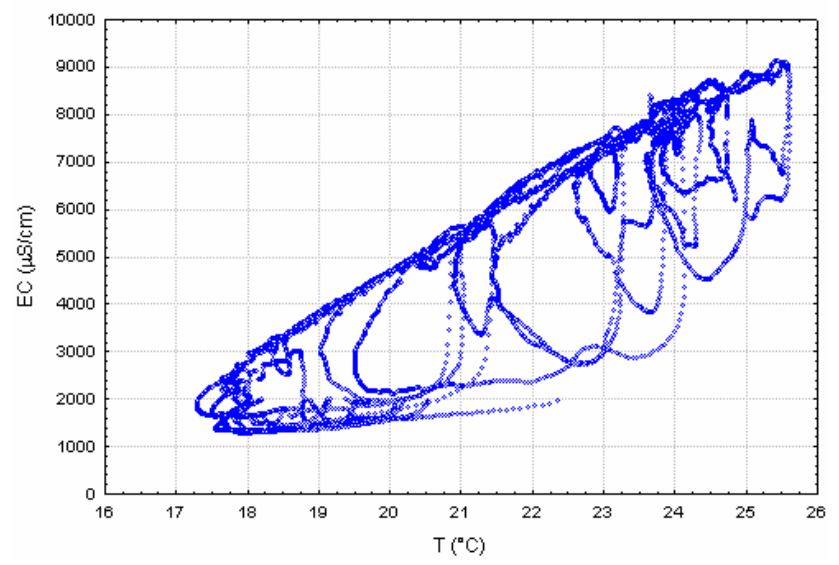

Fig. 18. EC vs. T scatterplot; time interval: 21 September 2003-4 June 2005.
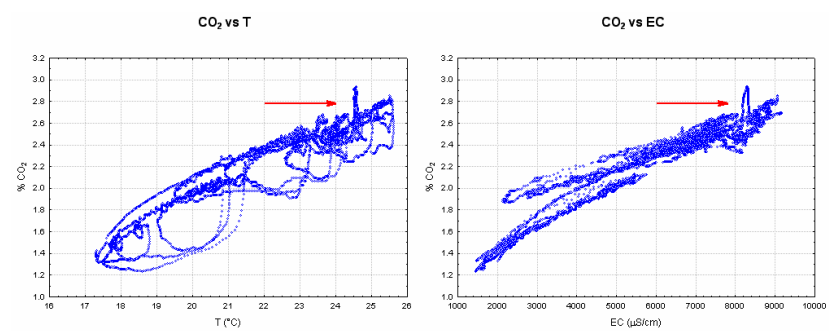

Fig. 19. $\mathrm{CO}_{2}$ vs. $\mathrm{T}$ and $\mathrm{CO}_{2}$ vs. EC scatterplot; time interval: 9 February 2004-4 June 2005.

In addition, such a correlation is characterised by a noticeable time delay (rainfall-dependant), which leads to trace regular orbits in the EC-T (Fig. 18) and $\mathrm{CO}_{2}$-T domains (Fig. 19). Moreover, the fact that the effect of a variation in the mixing ratio on the chemical-physical parameters is faster than the effect over the temperature, leads to larger orbits in the scatterplots involving $\mathrm{T}$ than in the one representing the $\mathrm{CO}_{2}$-EC. This is an expected behaviour due to the thermal capacity of the system where such mixing happens, which delays every effect over the temperature. Such particular features represent a good opportunity for studying techniques for removing unwanted correlations between informative parameters and sources of perturbation, in order to better select meaningful anomalies. In fact, the isolated lack of correlation found in the $\mathrm{CO}_{2}$ - $\mathrm{T}$ and $\mathrm{CO}_{2}$-EC scatterplots (see the red arrows in Fig. 19) appears to be informative: it suggests that there has been a sudden gas flux through the water body instead of the "slow" water mixing that characterises the typical behaviour of the system, where relatively fast $\mathrm{CO}_{2}$ increases at a constant temperature do not happen, while fast decreases followed by a delayed decrease in temperature may happen, due to the rainfall (see Figs. 16 and 19). 


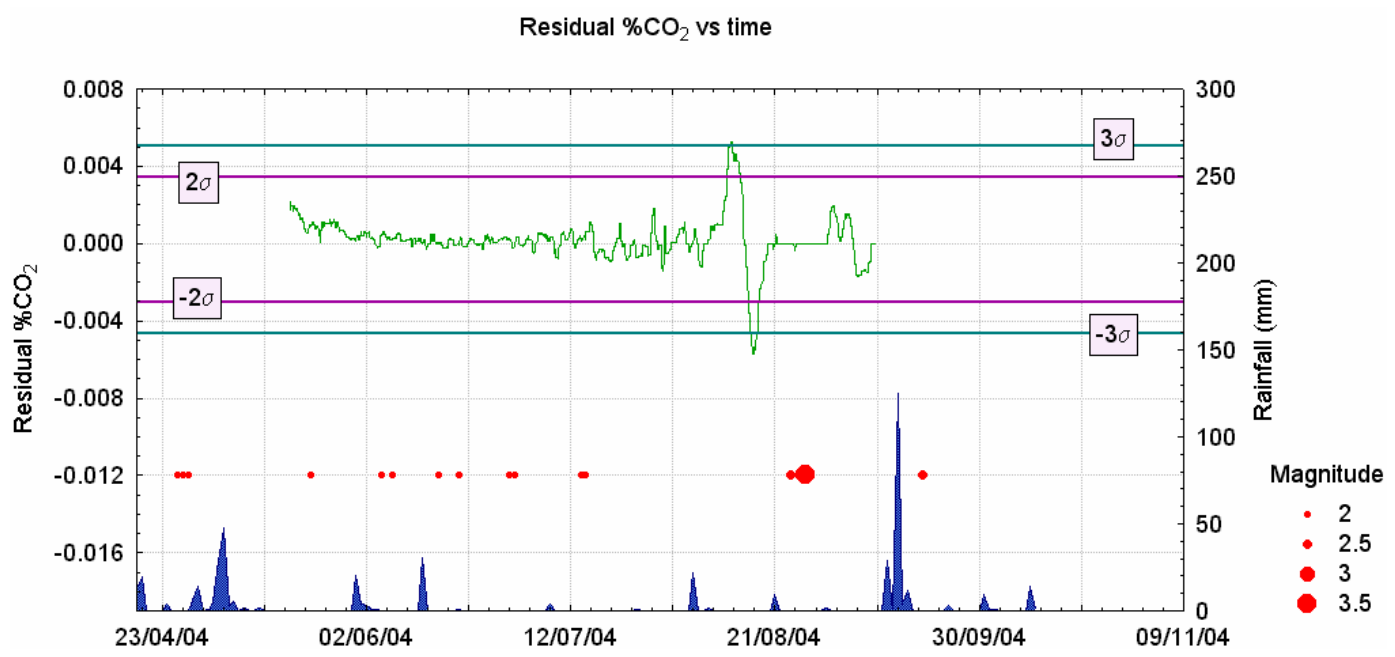

Fig. 20. The residual of $\mathrm{CO}_{2}$ signal vs. time. Time interval: 18 May 2004-9 September 2004.

An additional confirmatory step to assess an anomalous signal is to determine its deviation from its stationary behaviour in the time domain. Calculation of the autocorrelation coefficient for a time lag up to $48 \mathrm{~h}$ shows a strong autocorrelation of the $\% \mathrm{CO}_{2}$ signal. Such a situation suggests that uncorrelated residuals can be used as a possible way to determine anomalies; thus, the observed time series, shifted by one sample $(1 \mathrm{~h})$, has been subtracted from the original one, giving a series of finite difference values, the result of which is shown in Fig. 20. The irregular signal $\left(\% \mathrm{CO}_{2}\right.$ residual) peaks at \pm 3 from its average value in correspondence with the cited anomaly found in the scatterplot, reinforcing the evaluation of the anomaly.

On 27 August 2004 a $M=3.7$ earthquake with epicentre in the Apuan Alps ( $3 \mathrm{~km}$ horth of Equi Terme) occurred.

Even if this event does not give authorisation to indicate the above-described anomaly in the signals necessarily considered as precursory phenomena, the multidisciplinary approach utilised in this investigation allows us to describe the natural variability of the aquifer systems and shows several promising aspects regarding the assessment of possible earthquake precursors.

Acknowledgements. Thanks are due to the Seismic Service Office of Tuscany Region, Italy, that has financed this research. Authors are grateful to R. Drysdale (University of Newcastle, Australia) for reviewing the manuscript in its last version. Rainfall data recorded at the Aulla, Careggine, Villa Collemandina and Bagni di Lucca stations have been supplied by ARSIA, Pisa. Rainfall data recorded at the Castel del Piano station have been supplied by Ufficio Idrografico e Mareografico di Pisa.

Edited by: A. Loukas

Reviewed by: 3 referees

\section{References}

Baldacci, F. and Raggi, G.: Lineamenti geologici e idrogeologici della regione dell'Appennino Ligure Toscano a nord dell' Arno. Contributo alle conoscenze delle risorse geotermiche del territorio italiano, C.N.R., PFE-SPEG, RF 13, 68-85, 1982.

Baldacci, F., Cecchini, S., Lopane, G., and Raggi, G.: Le risorse idriche del bacino del fiume Serchio ed il loro contributo all'alimentazione dei bacini idrografici adiacenti, Mem. Soc. Geol. It., 49, 365-391, 1993.

Bencini, A., Duchi, V., and Martini, M.: Geochemistry of thermal springs of Tuscany, (Italy), Chemical Geology, 19, 229-252, 1977.

Bencini, A., Brondi, M., Dall'Aglio, M., Duchi, V., Quattrocchi, F., and Venni, G.: Ricerca di siti idonei all'istallazione di stazioni di monitoraggio di parametri idrogeochimici pertinenti ai terremoti, nell' area della Garfagnana, Atti GNGTS, 101-114, 1990.

Biagi, P. F., Ermini, A., Kingsley, S. P., Khatkevich, Y. M., and Gordeev, E. I.: Possible Precursors in Groundwater Ions and Gases content in Kamchatka (Russia). Phys. Chem. Earth, A, 25, 295-305, 2000.

Boschetti, T., Venturelli, G., Toscani, L., Barbieri, M., and Mucchibo, C.: The Bagni di Lucca thermal waters (Tuscany, Italy) an example of $\mathrm{Ca}-\mathrm{SO}_{4}$ waters with high $\mathrm{Na} / \mathrm{Cl}$ and low $\mathrm{Ca} / \mathrm{SO}_{4}$ ratios, J. Hydrol., 307, 270-293, 2005.

Calamai, A., Cataldi, R., Squarci, P., and Taffi, L.: Geology, Geophysics and Hydrogeology of the Monte Amiata Geothermal Field, Geothermics, Special Issue 1, 1-9, 1970.

Calvi, E., Caprai, A., Leone, G., and Mussi, M.: Isotopic and chemical composition of some thermal groundwaters and associated gases in the Serchio river valley, Northern Tuscany, Italy, Atti Soc. Tosc. Sci. Nat. Mem., Serie A, 106, 45-53, 1999.

Carapezza, M. L., Cioni, R., Guidi, M., Lelli, M., Pruiti, L., Ricci, T., and Scozzari, A.: The importance of automatic continuous geochemical monitoring in an open conduit volcano (Stromboli, Italy), EGS-EGU, Vienna, 2005.

Carmignani, L., Decandia, F. A., Fantozzi, P. L., Lazzarotto, A., Liotta , D., and Meccheri, M.: Tertiary extensional tectonics 
in Tuscany (Northern Appennines, Italy), Tectonophysics, 238, 295-315, 1994.

Celati, R., Grassi, S., and Calore, C.: Overflow thermal springs of Tuscany (Italy), J. Hydrol., 118, 191-207, 1990.

Chiodini, G., Cioni, R., Di Paola, G., Dotsika, E., Fytikas, M., Guidi, M., Leonis, C., Lyberopoulou, V., Magro, G., Marini, L., Meletidis, S., Michelot, J. L., Poutoukis, D., Raco, B., Russo, M., and Virgili, G.: Geochemistry of Santorini fluids, Final Report, Contract EV5V-CT93 (DG12 SOLS), 1996.

Cioni, R., Guidi, M., and Raco, B.: The Automatic Geochemical Monitoring of Volcanoes project, final Report on the research project supported by contract ENV4-CT96-0289 (DGXIIESCY), project co-ordinator: Allard, P., 1999.

Cioni, R. and Guidi, M.: European Mobile Early Warning System, final Report, Contract ENV4-CT98-0728 (DG12-ESCY), 2001.

Jolivet, L., Faccenna, C., Goffé, B., Mattei, M., Rossetti, F., Brunet, C., Storti, F., Funiciello, R., Cadet, J. P., D’Agostino, N., and Parra, T.: Midcrustal shear zones in postorogenic extension: example from the northern Tyrrhenian Sea, J. Geophys. Res., 103, 12 123-12 160, 1998.

De Stefani, C.: Le acque termali di Torrite in Garfagnana, Boll. Soc. Geol. It., XXIII, I, 117-148, 1904.

Duchi, V., Minissale, A., Paolieri, M., Prati, F., and Valori, A.: Chemical relationship between discharging in the SienaRadicofani graben by the geothermal field of the Mt. Amiata, Torre Alfina and Latera (central Italy), Geothermics, 21, 401413, 1992.

Eva C., Giglia G., Graziano F., and Merlanti, F.: Seismicity and its relation with surface structures in the North-Western Apennines, Boll. Geof. Teor. Appl., XX, 79, 263-277, 1978.

Fancelli, R. and Nuti, S.: Studio sulle acque geotermiche e minerali della parte orientale della provincia di Siena, Boll. Soc. Geol. It., 94, 135-155, 1975.

Fancelli, R. and Agostini, G.: Le acque di Bagni di Lucca nei loro rapporti con le altre manifestazioni idrotermali nella Toscana settentrionale, Atti delle giornate Bagni di Lucca Terme; Bagni di Lucca, 3-4 maggio 1980.

Fanelli, M., Bellucci, L., and Nachira, F.: Manifestazioni idrotermali italiane. CNR - PFE, Geothermal Energy Subproject RF 13, Appendix, 1982.

Francalanci, G. P.: Contributo per la conoscenza delle manifestazioni idrotermali della Toscana, Atti Soc. Toscana Sci. Nat., Serie A 65, 373-432, 1959.

Frepoli, A. and Amato, A.: Contemporaneous extension and compression in the Northern Apennines from earthquake fault-plane solutions, Geophys. J. Int., 129, 368-388, 1997.

Frepoli, A. and Amato, A.: Spatial variation in stress in peninsular Italy and Sicily from background seismicity, Tectonophysics, 317, 109-124, 2000.

Garavaglia, M., Braitenberg, C., Zadro, M., and Quattrocchi, F.: Radon measurements in soil and water in the seismic Friuli area, Il Nuovo Cimento, 22C, 415-422, 1999.

Hartmann, J. and Levy, J.: The influence of seismotectonics on the precursory changes in groundwater composition for the earthquake, Japan, Hydrol. J., 14, 1307-1318, 2006.

Johansen, A., Saleur, H., and Sornette, D.: New evidence of earthquake precursory phenomena in the 17 January 1995 Kobe earthquake, Japan, The European Physical Journal B, 15, 551-555, 2000.
Johansen, A., Sornette, D., Wakita, H., Tsunogai, U., Newman, W., and Saleur, H.: Discrete scaling in earthquake precursory phenomena: evidence in the Kobe earthquake, Japan, J. Phys. I France, 6, 1391-1402, 1996.

King, C. Y.: Gas geochemistry applied to earthquake prediction: an overview, J. Geophys. Res., 91, B12, 12 269-12 281, 1986.

King, C. Y.: Gas geochemical approaches to earthquake prediction, In: Radon Monitoring in Radioprotection, Environmental RadioActivity and Earth Sciences, ICTP, Trieste, 244-277, 1989.

Langelier, W. F. and Ludwig, H. F.: Graphical methods for indicating the mineral character of natural waters, J. Am. Water Works Ass., 34, 335-350, 1942.

Marinelli, G.: Genèse des magmas du volcanisme Plio-Quaternaire des Apennines, Geol. Rundsch., 57, 127-141, 1967.

Masini, R.: Studi geoidrologici sulle acque fredde e calde (Alpi Apuane e bacino del Serchio), Boll. Servizio Geologico d'Italia, 78, 709-788, 1956.

Masini, R.: Le terme di Equi (Alpi Apuane) e l'origine delle sorgenti termominerali, Boll. Servizio Geologico d'Italia, 85, 95125, 1964.

Meletti, C. and Valensise, G.: Zonazione sismogenetica ZS9. Gruppo di lavoro per la redazione della mappa di pericolosità sismica, zonesismiche.mi.ingv.it/documenti/App2.pdf, 2004.

Nucci, M., Marchetti, G., Guidi, M., Zanzari, A. R., Scozzari, A., and Galli, G.: Geochemical responses of the aquifers to the seismic events: the Micrat project, AVR05 Aquifer Vulnerability and Risk International Workshop, Piacenza, 2005.

Peccerillo, A.: Multiple mantle metasomatism in central southern Italy: geochemical effects, timing and geodynamic implications, Geology, 27, 315-318, 1999.

Pieri, C. and Burichetti, E.: L'acqua termale di Pieve Fosciana. Analisi, indagini e considerazioni chimico-fisiche, Atti Soc. tosc. Sci. Nat. Mem., 40, 1-20, 1930.

Pulinets, S. A. and Dunajecka, M. A.: Specific variations of air temperature and relative humidity around the time of Michocan earthquake M8.1, 19 September 1985 as a possible indicator of interaction between tectonic plates, Tectonophysics, 431, 221230, 2007.

Quattrocchi, F. and Calcara, M.: Test-site for earthquake prediction experiments within the Colli Albani region, Phys. Chem. Earth, 23, 915-920, 1998.

Quattrocchi, F., Guerra, M., Pizzino, L., and Lombardi, S.: Radon and helium as pathfinders of fault systems and groundwater evolution in different Italian Areas, Il Nuovo Cimento, 22 C, 309 316, 1999.

Rosini, R., Di Luccio, F., and Barba, S.: Focal mechanism in the Apennines, Phys. Chem. Earth, 21, 273-278, 1997.

Serri, G., Innocenti, F., and Manetti, P.: Geochemical and petrological evidence of the subduction of delaminated Adriatic continental lithosphere in the genesis of the Neogene-Quaternary magmatism in central Italy, Tectonophysics, 223, 117-147, 1993.

Singh, R., Cervone, G., Singh, V., and Kafatos, M.: Generic precursors to coastal earthquakes: Inferences from Denali fault earthquake, Tectonophysics, 431, 231-240, 2007.

Thomas, D.: Geochemical precursors to seismic activity, PAGEOPH, 126, 241-266, 1988.

Toutain, J. P., Baubron, J. C.: Gas geochemistry and seismotectonics: a review, Tectonophysics, 304, 1-27, 1999.

Trevisan, L., Dallan, L., Federici, P. R., Giglia, G., Nardi, R., and 
Raggi, G.: Foglio 96 Massa, Note illustrative della Carta geologica d'Italia, scala 1:100.000, Servizio geologico d'Italia, 1971.

Ulomov, V. I. and Mavashev, B. Z.: Forerunners of the Taskent earthquake, Izvestia Akadamiyi Nauk Uzbeckistan SSR, 188200, 1967.

Wakita, H.: Water wells as possible indicators of tectonic strain, Science, 189, 553-555, 1975.

Wyss, M. and Booth, D. C.: The IASPEI procedure for the evaluation of earthquake precursors, Geophys. J. Int., 131, 423-428, 1997.
Zanzari, A. R., Martinelli, A., Cioni, R., Guidi, M., Raco, B., Scozzari, A., Quattrocchi, F., Galli, G., and Mancini, C.: Discrete and continuous monitoring of groundwater in the seismic area of the Umbria region (Italy), Proceeding of Water-Rock Interaction 2001, edited by: Cidu, R., Swets, J. A., and Zeitlinger, N. V., Lisse, ISBN 902651824 2, 1, 119-122, 2001. 